\title{
SKARGA NA WYROK SĄDU ODWOLAWCZEGO JAKO ŚRODEK ZASKARŻENIA W POSTĘPOWANIU KARNYM
}

I. Instytucja skargi na wyrok sądu odwoławczego uchylający wyrok sądu pierwszej instancji i przekazujący sprawę do ponownego rozpoznania (skargi na wyrok sądu odwoławczego) została wprowadzona na grunt polskiego postępowania karnego na mocy ustawy z 11 marca 2016 r. o zmianie ustawy - Kodeks postępowania karnego oraz niektórych innych ustaw ${ }^{1}$, która weszła w życie 15 kwietnia $2016 \mathrm{r}$. Z uzasadnienia projektu tej ustawy wynika, że prawodawca potraktował skargę jako mechanizm służący zabezpieczeniu reformatoryjności orzekania, a w konsekwencji - „eliminowaniu bezzasadnych uchyleń wyroków, co bez wątpienia wpływa na przyspieszenie postępowania”. W dokumencie tym wyeksponowano funkcję prewencyjną nowo wprowadzanego środka, polegająca na „powstrzymywaniu sądu odwoławczego przed pochopną kasatoryjnością orzekania”, a zastrzeżenie jego rozpoznawania do wyłącznej kompetencji Sądu Najwyższego (SN) motywowano potrzebą zapewnienia jednolitości orzecznictwa ${ }^{2}$.

$\mathrm{Na}$ etapie prac legislacyjnych w opiniach dotyczacych projektu ustawy środowiska prawnicze zgłaszały zastrzeżenia co do tej propozycji. Krytyczne uwagi podważały zarówno sens wprowadzenia wspomnianego środka zaskarżenia do polskiego procesu karnego, jak i trafność poszczególnych rozwiązań wyznaczajacych jego kształt ${ }^{3}$. Nowa instytucja nie wzbudziła również entuzjazmu wśród przedstawicieli doktryny. W licznych opracowaniach poświęconych tej kwestii zdecydowanie negatywnie oceniano regulacje zawarte w nowo wprowadzonym rozdziale 55a k.p.k. ${ }^{4}$

\footnotetext{
${ }^{1}$ Dz. U. 2016, poz. 437 ze zm. (dalej jako: nowela marcowa).

${ }^{2}$ Uzasadnienie projektu ustawy - o zmianie ustawy - Kodeks postępowania karnego oraz niektórych innych ustaw, druk sejmowy nr 207 z 27 stycznia2016 r.: 11.

${ }^{3}$ Opinia Ośrodka Badań, Studiów i Legislacji Krajowej Rady Radców Prawnych dotycząca projektu ustawy o zmianie ustawy - Kodeks postępowania karnego oraz niektórych innych ustaw (druk sejmowy nr 207) z 2 lutego 2016 r.: 18-19; Stanowisko Prezydium Krajowej Rady Sądownictwa z 8 lutego $2016 \mathrm{r}$. w przedmiocie projektu ustawy projektu ustawy o zmianie ustawy - Kodeks postępowania karnego oraz niektórych innych ustaw (druk sejmowy nr 207 z 27 stycznia 2016 r.: 5-6; Uwagi Sądu Najwyższego do projektu ustawy o zmianie ustawy - Kodeks postępowania karnego oraz niektórych innych ustaw (druk sejmowy nr 207, wersja projektu z 27 stycznia 2016 r.), pkt VIII: $22-25$.

${ }^{4}$ Zob. w szczególności: Czarnecki (2016): 77-105; Gil (2016): 81-95; Steinborn (2017) oraz Zagrodnik (2017).
} 
W związu z faktem, że wspomniane oceny wyrażane były w czasie procesu legislacyjnego albo też krótko po wejściu w życie analizowanych przepisów, a więc zanim przeszły one „test praktycznej weryfikacji”, podjętej na łamach przedmiotowego artykułu problematyki nie można uznać za wyczerpana. Dopiero funkcjonowanie danej instytucji w praktyce pozwala ocenić, czy oczekiwania czy też obawy związane z jej wprowadzeniem były uzasadnione, a nadto odkryć wcześniej niedostrzegane jej zalety bądź wady.

Od razu należy jednak zastrzec, że podstawowy błąd w sztuce prawodawczej, popełniony jeszcze przed przygotowaniem projektu ustawy, nadal nie pozwala na udzielenie stanowczej odpowiedzi na pytanie, czy analizowany instrument rzeczywiście był potrzebny i spełnił pokładane w nim przez ustawodawcę nadzieje, tj. wpłynął na przyspieszenie postępowania i zmniejszył liczbę orzeczeń o charakterze kasatoryjnym wydawanych przez sądy odwoławcze. Wprowadzenie analizowanych regulacji po upływie zaledwie 9 miesięcy od dnia wejścia w życie przepisów mających na celu zwiększenie reformarotyjności orzekania $\mathrm{w}$ toku postępowania apelacyjnego uniemożliwia przeprowadzenie badań, które dałyby szansę na sformułowanie jakichkolwiek stanowczych wniosków w tym przedmiocie. Do tego konieczne byłoby zbadanie, na reprezentatywnej próbie spraw, ile orzeczeń kasatoryjnych w nowym zreformowanym modelu postępowania odwoławczego zapadało, zanim przepisy o tytułowej skardze weszły w życie i zaczęły realnie funkcjonować, a ile po tym czasie. W tym przypadku jest to jednak niemożliwe, gdyż sądy odwoławcze nie zdążyły wydać orzeczeń na podstawie przepisów wyznaczajacych nowy model postępowania odwoławczego przed wejściem w życie regulacji ujętych w rozdziale 55a k.p.k. Przypomnieć bowiem należy, że zarówno przepisy wyznaczajace ów model, jak i regulacje dotyczace skargi na wyrok sądu odwoławczego stosuje się do spraw, w których akt oskarżenia wpłynął do sądu po 30 czerwca 2015 r. (art. 36 pkt 2 ustawy z 27 września 2013 r. o zmianie ustawy - Kodeks postępowania karnego oraz niektórych innych ustaw oraz art. 25 ust. 2 noweli marcowej).

Opisany stan rzeczy jest konsekwencją faktu, że ustawodawca, zreszta nie po raz pierwszy, nie przywiązał należytej wagi do tego, że u podstaw tworzenia prawa winna leżeć dyrektywa minimalizacji interwencji prawodawczej, w myśl której nie należy wybierać użycia środka prawnego (względnie nowego środka prawnego), jeżeli zastosowanie innych środków (względnie dotychczasowych środków prawnych) jest oceniane jako skuteczne ${ }^{5}$. Wyrazem obowiązywania tej zasady są przepisy, ujęte zarówno w „Zasadach techniki prawodawczej”, jak i Regulaminie Sejmu RP, które wymagaja, między innymi, by decyzję o przygotowaniu projektu ustawy poprzedzało badanie stanu stosunków społecznych w dziedzinie, która ma być przedmiotem regulacji, oraz analiza aktualnego stanu prawnego, przeprowadzone w sposób umożliwiający wykazanie różnic pomiędzy dotychczasowym a oczekiwanym stanem faktycznym i prawnym oraz wyprowadzenie stanowczej konkluzji, że w aktualnych warunkach proponowane rozwiązania prawne maja charakter

\footnotetext{
${ }^{5}$ Por. Wierczyński (2003): komentarz do § 1 załącznika, teza 7.
} 
optymalny $^{6}$. Na kwestie te wielokrotnie zwracał uwagę Trybunał Konstytucyjny (TK), podkreślając, że ingerencja prawodawcza jest dopuszczalna wyłącznie wówczas, gdy zakłada adekwatność środka i celu, gdyż ustawodawca powinien tak kształtować prawo, aby stanowiło skuteczny środek do osiagania założonego celu. Wymaga to od prawodawcy dokonywania każdorazowo oceny skutków ubocznych, jakie przyniesie ze sobą projektowane unormowanie i porównania ich z wartością zamierzonego celu. Stwierdzenie, że efekty uboczne będą przekraczać wartość owego celu, winno natomiast skutkować uznaniem ocenianej regulacji za niezgodna z racjonalnym modelem tworzenia prawa i w konsekwencji zaniechaniem jej wprowadzenia ${ }^{7}$. Obowiązku tego nie wolno bagatelizować, albowiem każda ingerencja prawodawcza wiąże się ze stratami i kosztami powstającymi przez sam fakt zmiany w systemie prawa, która osłabia tak ważne jego cechy, jak stabilność czy trwałość ${ }^{8}$. Takich analiz jednak, jak sygnalizowano wyżej, prawodawca w tym przypadku nie tylko nie przeprowadził, ale i - przez przedwczesne wprowadzenie przedmiotowej instytucji na grunt polskiego procesu karnego - wykluczył ich przeprowadzenie także w przyszłości. Aktualnie zatem ewentualne wnioski co do przydatności tytułowego środka można opierać wyłącznie na wynikach badań dotyczacych postępowań zainicjowanych jego wniesieniem, przeprowadzonych zwłaszcza pod katem wykazania, ile skarg okazało się zasadnych i jaki czas upłynął od daty wydania wyroku sądu odwoławczego do dnia rozpoznania skargi przez SN. Z powodów wskazanych wyżej, niezależnie jednak od tego, jak będą przedstawiały się wyniki tych analiz, wyprowadzane z nich wnioski nie będą miały charakteru stanowczego i pewnego.

II. Przed przystapieniem do rozważań dotyczących funkcjonowania tytułowej instytucji w praktyce należy zbadać, czy sam sposób jej ustawowego ujęcia był prawidłowy i przynajmniej z teoretycznego puntu widzenia umożliwiał realizację celów, jakie ustawodawca wiązał z jej wprowadzeniem.

Z usytuowania rozdziału 55a, który został zamieszczony w dziale XI Kodeksu postępowania karnego, zatytułowanym „Nadzwyczajne środki zaskarżenia”, można wstępnie wnioskować, że skarga na wyrok sądu odwoławczego jest nadzwyczajnym środkiem zaskarżenia. Zastrzeżenie „wstępnie” jest na tym etapie konieczne, albowiem choć tytuły działów i rozdziałów ustawy odgrywają istotna rolę przy interpretacji tekstu prawnego, to nie mogą zostać uznane za przesądzające o charakterze instytucji, której dotyczą zawarte

${ }^{6}$ § 1 załącznika do rozporządzenia Prezesa Rady Ministrów z 20 czerwca 2002 r. w sprawie Zasad techniki prawodawczej (t.jedn.: Dz. U. 2016, poz. 283) oraz art. 34 ust. 2 uchwały Sejmu Rzeczypospolitej Polskiej z 30 lipca 1992 r. Regulamin Sejmu Rzeczypospolitej Polskiej (t.jedn.: M.P. 2012, poz. 32 ze zm.).

7 Zob. wyrok TK z 18 października 2001 r., SK 2/10, OTK-A 2011, z. 8, poz. 83; orzeczenie TK z 20 listopada 1996 r., K 27/95, OTK 1996, z. 6, poz. 50.

8 Wierczyński (2003): komentarz do $§ 1$ załącznika, teza 7. 
w danym dziale/ rozdziale regulacje $\mathrm{e}^{9}$. Prawodawcy zdarza się bowiem, czasem i nieświadomie, popełniać błędy na tym polu ${ }^{10}$. W analizowanym przypadku co wynika wprost z uzasadnienia projektu ustawy, gdzie wyraźnie nazwano skargę na wyrok sądu odwoławczego nadzwyczajnym środkiem zaskarżenia - decyzja o zamieszczeniu regulacji dotyczących skargi na wyrok sądu odwoławczego w dziale XI była z pewnością decyzją świadomą. Z formalnego punktu widzenia potraktowanie skargi jako nadzwyczajnego środka zaskarżenia również nie nasuwa zastrzė̇eń.

Podstawową cechą nadzwyczajnych środków zaskarżenia, odróżniającą je od zwyczajnych środków zaskarżenia, jest wszak to, że przysługują od orzeczeń prawomocnych. I taki charakter wyrok sądu odwoławczego, uchylający zaskarżony wyrok i przekazujacy sprawę do ponownego rozpoznania, mimo jego specyfiki i zgłaszanych w doktrynie wątpliwości ${ }^{11}$, posiada. Nie podlega wszak zaskarżeniu za pomoca zwykłych środków zaskarżenia, a ponadto nie jest możliwe ponowne orzekanie przez instancję odwoławczą w przedmiocie już raz rozpoznanego środka odwoławczego. Gdyby tak się stało, orzeczenie sądu odwoławczego dotknięte byłoby uchybieniem stanowiącym bezwzględna przyczynę odwoławczą z art. $439 \S 1$ pkt 8 k.p.k. w zw. z art. $17 \S 1$ pkt 7 k.p.k. Oznacza to, że przedmiotowy wyrok ma charakter imperatywny i niewzruszalny ${ }^{12}$, a idem, w tym układzie procesowym, stanowi środek odwoławczy wniesiony od określonego, konkretnego wyroku sądu pierwszej instancji ${ }^{13}$.

Natomiast tym, co odróżnia kasatoryjny wyrok sądu odwoławczego od orzeczeń podlegających zaskarżeniu w drodze innych nadzwyczajnych środków zaskarżenia, jest bez wątpienia to, że przedmiotowe orzeczenie nie kończy postępowania w sprawie. I właśnie ze wspomnianym charakterem wyroku, podlegającego zaskarżeniu tytułową skarga, należy wiązać decyzję ustawodawcy czyniącą z niej środek zaskarżenia o charakterze bezwzględnie suspen-

${ }^{9} \mathrm{Z}$ tego też powodu nie można zgodzić się z poglądem, że umieszczenie regulacji dotyczących skargi w dziale XI Kodeksu postępowania karnego stanowi najbardziej wymierne kryterium przy ustalaniu, czy skarga z art. 539a k.p.k. jest nadzwyczajnym czy zwyczajnym środkiem zaskarżenia - Pawlikowska, Wantoła (2016): 326.

${ }_{10}$ Dość wspomnieć o sporach interpretacyjnych, jakie wywołało np. umieszczenie przez ustawodawcę regulacji dotyczących poszukiwania oskarżonego, listu gończego w dziale dotyczącym środków przymusu. Część przedstawicieli doktryny konsekwentnie i zasadnie odmawia tym instytucjom charakteru środków przymusu, uznając je za czynności poszukiwawcze, a jedynej przyczyny umieszczenia przepisów dotyczących wspomnianych instytucji w tym dziale upatruje w pewnym związku ze środkami zapobiegawczymi - zob. w szczególności: Kulesza (2012): 275; Koper (2017): 413; Hofmański, Waltoś (2018): 426.

11 Kaftal (1966): 102-103; Marszał (2017): 718, zob. także Zagrodnik (2017).

12 Piasecki (1962): 27-28.

13 Jest to zgodne $\mathrm{z}$ koncepcją nadającą pojęciu idem szerszy zakres znaczeniowy i rozumiejąca przez nie kwestię prawna, która została prawomocnie rozstrzygnięta w toku postępowania karnego - Hofmański (1988): 126. W doktrynie wskazuje się, że postępowaniem tym może być zarówno postępowanie zasadnicze, gdzie idem stanowi kwestia odpowiedzialności karnej za czyn przestępny, jak i postępowanie dodatkowe. W tym drugim przypadku jako idem należy traktować kwestię, której dotyczyło to postępowanie - Steinborn (2009). Oznacza to, że jeśli na idem spojrzymy przez pryzmat poszczególnych etapów postępowania karnego, nie ma przeszkód, by jako idem traktować kwestię rozpoznania skargi, która ów etap rozpoczęła - Steinborn (2011): rozdział 1, pkt 4.2. 
sywnym (art. 539b § 2 k.p.k.). Irracjonalne byłoby bowiem, by środek, który został pomyślany jako instrument majacy na celu eliminowanie wadliwych kasatoryjnych orzeczeń sądu odwoławczego, przekazujących sprawę sądowi a quo do ponownego rozpoznania, nie wstrzymywał tej procedury. Brak bezwzględnej suspensywności podważałby istotę środka, którego uwzględnienie może skutkować wydaniem przez SN tylko jednego orzeczenia, a mianowicie uchylającego wyrok sądu odwoławczego w całości lub w części i przekazującego sprawę sądowi odwoławczemu do ponownego rozpoznania (art. 539e $§ 2$ k.p.k. ${ }^{14}$. Jest oczywiste, że takie orzeczenie, mając na uwadze treść art. 17 $\S 1$ pkt 7 k.p.k., nie mogłoby zostać wydane, gdyby toczące się ponownie postępowanie co do tego samego czynu tej samej osoby było w toku albo zostało prawomocnie zakończone.

Z powyższych przyczyn bezwzględna suspensywność skargi nie może być traktowana jako argument wspierajacy tezę, że stanowi ona środek odwoławczy, a nie nadzwyczajny środek zaskarżenia ${ }^{15}$. Ponadto należy zauważyć, że zażalenie, mimo że jest środkiem odwoławczym, jest jedynie względnie suspensywne (art. $462 \S 1$ k.p.k.), a taki charakter mają przecież i kasacja, i wniosek o wznowienie postępowania (art. $532 \S 1$ k.p.k., art. $532 \S 1$ k.p.k. w zw. z art. $545 \S 1$ k.p.k.).

III. Za okoliczności silnie wspierające tezę, że skarga na wyrok sądu odwoławczego jest nadzwyczajnym środkiem zaskarżenia, należy niewątpliwie uznać zastrzeżenie jej rozpoznania, tak jak w przypadku kasacji, do wyłacznej właściwości SN, a ponadto ograniczony, w porównaniu z postępowaniem odwoławczym, zakres kognicji organu orzekającego w tym postępowaniu ${ }^{16}$.

Rozwijając ten ostatni wątek, wspomnieć należy, że zgodnie z art. 539a $§ 3$ k.p.k. skarga może być wniesiona wyłącznie z powodu naruszenia art. 437 lub z powodu uchybień określonych w art. $439 \S 1$ k.p.k. Mimo że powołany przepis odsyła do całego art. 437 k.p.k., nie budzi wątpliwości, że podstawą skargi może być zarzut naruszenia przez sąd odwoławczy przepisu art. 437 § 2 k.p.k., który stanowi, że uchylenie orzeczenia i przekazanie sprawy do ponownego rozpoznania może nastapić wyłącznie w wypadkach wskazanych w art. 439 $\S 1$ k.p.k., art. 454 k.p.k. lub jeżeli jest konieczne przeprowadzenie na nowo przewodu sądowego w całości ${ }^{17}$. Nie można przy tym zgodzić się poglądem, że wymienienie w treści przepisu art. 539a $§ 3$ k.p.k., obok art. 437 k.p.k., przepisu art. $439 \S 1$ k.p.k. jest zbędne z uwagi na fakt, że w treści art. $437 \S 2$ k.p.k.

14 Zob. też Lach (2017): 266.

15 Por. Gil (2016): 85.

${ }^{16}$ Za kryteria mające decydujące znaczenie przy ustalaniu, czy daną instytucję należy zaliczyć do nadzwyczajnych środków zaskarżenia, najczęściej wskazuje się: rodzaj orzeczenia, od którego przysługuje ów środek, podstawy jego do wniesienia środka oraz zakres orzekania w ramach prowadzonej kontroli - Kaftal (1971): 58.

17 Wyrok SN z 23 maja 2018 r., IV KS 10/18, Lex nr 2515852. W związku z tym należy zgodzić się z wyrażanym w doktrynie poglądem, że odesłanie w art. 539a § 3 k.p.k. do całego art. 437 k.p.k. jest zbyt szerokie - Szymczykiewicz (2016): 103). 
wskazano ostatnio wspomnianą regulację ${ }^{18}$. Należy bowiem wskazać, że poprzestanie na przywołaniu w treści art. 539a § 3 k.p.k. tylko art. 437 k.p.k. uprawniałoby skarżącego do opierania skargi na zarzucie dotyczacym art. 439 $\S 1$ k.p.k. jedynie w sytuacji, w której sąd odwoławczy naruszyłby ów przepis, wadliwie uznając, że wyrok sądu pierwszej instancji dotknięty jest uchybieniem stanowiącym bezwzględną przyczynę odwoławczą uzasadniająca wydanie orzeczenia uchylającego zaskarżony wyrok i przekazującego sprawę do ponownego rozpoznania organowi a quo. Aktualne brzmienie art. 539a § 1 k.p.k. upoważnia natomiast do podnoszenia w skardze samodzielnego zarzutu zaistnienia uchybienia o randze bezwzględnej przyczyny odwoławczej na etapie postępowania apelacyjnego ${ }^{19}$.

Wbrew, wydawałoby się, jasnej treści art. 539a $§ 3$ k.p.k. wyznaczony treścią skargi ${ }^{20}$ zakres kontroli wyroku sądu odwoławczego dokonywanej przez SN wywołuje wątpliwości w doktrynie i orzecznictwie. Już prima facie wydaje się, że zakres badania sprawy przez SN nie powinien być ograniczony jedynie do formalnego przesądzenia, czy powołana przez sąd odwoławczy przyczyna uchylenia orzeczenia mieści się w katalogu przesłanek z art. $437 \S 2$ k.p.k., a konieczne jest, by SN - po pozytywnym rozstrzygnięciu tej kwestii - był zobowiązany do ustalenia, czy dokonana w tym zakresie ocena sadu ad quem była prawidłowa ${ }^{21}$. Watpliwości wywołuje jednak kwestia tego, jak szeroki ma być zakres tej oceny.

O ile bowiem oczywiste jest, że w postępowaniu zainicjowanym analizowana skarga SN jest uprawniony i zobowiązany do badania, czy stwierdzone przez sąd odwoławczy uchybienie, które w ocenie instancji ad quem stanowi bezwzględną przyczynę odwoławczą, zaistniało w rzeczywistości ${ }^{22}$, o tyle

18 Gil (2016): 88; Szymczykiewicz (2016): 103.

19 Tak też Tęcza-Paciorek, Wróblewski (2017): 34.

${ }^{20} \mathrm{~W}$ postępowaniu zainicjowanym skargą na wyrok sądu odwoławczego stosuje się bowiem (na mocy odesłania zawartego w art. $539 f$ k.p.k.) art. 536 k.p.k., który stanowi, że SN rozpoznaje kasację w granicach zaskarżenia i podniesionych zarzutów, a w zakresie szerszym - tylko w wypadkach określonych w art. 435, 439 i 455 k.p.k.

21 Taki pogląd wyraził SN w uzasadnieniu uchwały 7 sędziów z 25 stycznia 2018 r., I KZP 13/17, OSNKW 2018, z. 3, poz. 23, stwierdzając, że niezależnie od podstawy wydania wyroku kasatoryjnego, kontrola w trybie skargi nie może ograniczyć się tylko do sprawdzenia, czy sąd odwoławczy podał formalnie dopuszczalną podstawę uchylenia wyroku i przekazania sprawy do ponownego rozpoznania, ale konieczne jest zbadanie w realiach konkretnej sprawy, czy rzeczywiście istniała taka podstawa.

22 Stanowisko takie zają SN w uzasadnieniu powołanej wyżej uchwały, stwierdzając, że: „w przypadku postawienia w skardze zarzutu naruszenia art. $437 \S 2$ zd. 2 k.p.k. w związku z art. 439 § 1 k.p.k. kontrola skargowa wymaga dokonania oceny, czy rzeczywiście zaistniało uchybienie o charakterze bezwzględnej przyczyny odwoławczej, a nie tylko tego, czy zostało ono wskazane jako podstawa uchylenia wyroku i przekazania sprawy do ponownego rozpoznania. Oznacza to badanie w sposób pośredni prawidłowości wyroku sądu pierwszej instancji. Uchybienia wymienione w art. $439 \S 1$ k.p.k. mogą zostać stwierdzone przez sąd odwoławczy z urzędu, jak i na skutek zarzutu odwoławczego (art. $433 \S 1$ k.p.k.). W tym drugim przypadku kontrola w trybie skargi naruszenia art. $437 \S 2$ zd. 2 k.p.k. w związku z art. $439 \S 1$ k.p.k. ze swej istoty dotyczyć będzie zasadności uwzględnienia zarzutu apelacji. Nie jest to jednak kontrola merytorycznego rozpoznania sprawy, tylko badanie, czy wyrok sądu pierwszej instancji dotknięty jest uchybieniem określonym w art. 439 § 1 k.p.k.”. 
wątpliwości wywołuje już to, czy - a jeśli tak, to w jakim obszarze - SN jest uprawniony do badania, czy trafna jest ocena sądu drugiej instancji, że zachodzi potrzeba zmiany zaskarżonego orzeczenia uniewinniającego (umarzajacego postępowanie/ warunkowo umarzającego postępowanie) i wydanie wyroku skazującego, czy też zaostrzenia kary przez orzeczenie kary dożywotniego pozbawienia wolności, albo że konieczne jest ponowne przeprowadzenie przewodu sądowego w całości.

Sąd Najwyższy w postanowieniu z 15 lutego 2018 r. (III KS 12/17) stwierdził, że w postępowaniu wywołanym skarga na wyrok sądu odwoławczego nie może oceniać, czy zaistniały merytoryczne podstawy, określone w art. 454 k.p.k., do wydania wyroku zmieniającego - a to z uwagi na fakt, że nie jest władny na podstawie przepisu art. 539a $\S 1$ k.p.k. do oceniania materiału dowodowego przedstawionego w sprawie. Rozpoznanie sprawy w tym zakresie należy bowiem do sądów powszechnych, natomiast interwencja SN w ten zakres orzekania stanowiłaby naruszenie ich ustawowych kompetencji ${ }^{23}$.

Poglądu tego nie można w pełni podzielić. Jego całkowita akceptacja byłaby równoznaczna z twierdzeniem, że do uznania wyroku kasatoryjnego za trafny wystarczające stanie się ustalenie, że sąd odwoławczy powołał się na przesłankę z art. $454 \S 1$ lub 3 k.p.k., a to podważałoby całkowicie sens prowadzonej przez SN kontroli. W związku z powyższym trzeba stwierdzić, że $\mathrm{w}$ postępowaniu zainicjowanym skargą na wyrok sądu odwoławczego SN jest zobowiązany badać, czy decyzja sądu odwoławczego, że zachodzi konieczność uchylenia zaskarżonego wyroku z uwagi na reguły ne peius, była trafna. Powyższe będzie wymagało ustalenia, czy stwierdzone przez sąd odwoławczy uchybienie winno skutkować uchyleniem zaskarżonego wyroku sądu pierwszej instancji do ponownego rozpoznania na jednej ze wskazanych wyżej podstaw. Oznaczać to będzie konieczność przeprowadzenia merytorycznej, a nie tylko formalnej oceny zasadności podniesionego w skardze zarzutu. Trafność tego stanowiska potwierdzają między innymi te judykaty SN, w których - uznając skargę na kasatoryjny wyrok sądu odwoławczego za zasadna - wskazywano, że wydanie wyroku uchylającego zaskarżony wyrok i przekazującego sprawę do ponownego rozpoznania na podstawie art. $454 \S 1$ k.p.k. było przedwczesne z uwagi na fakt, że sąd odwoławczy nie poprzedził tej decyzji usunięciem stwierdzonych uchybień, stanowiących jedną z podstaw odwoławczych określonych w art. 438 pkt $1-3$ k.p.k. ${ }^{24}$

Z powyższych wywodów nie wynika jednak - i w tym zakresie należy się ze stanowiskiem wyrażonym w postanowieniu w sprawie III KS 2/17 zgodzić - że SN w toku postępowania skargowego jest uprawniony do badania istoty sprawy oraz ponownego przeprowadzania całościowej kontroli odwoławczej. Takich kompetencji przepis art. 539a $§ 3$ k.p.k. bez watpienia mu nie przyznaje ${ }^{25}$.

${ }^{23}$ Lex nr 2456366.

${ }^{24}$ Zob. np. wyrok SN z 25 września 2018 r., V KS 18/18, Lex nr 2565821.

${ }^{25}$ Pogłębiony wywód poświęcony tej kwestii, odwołujący się do argumentów natury językowej i systemowej, czytelnik znajdzie w uzasadnieniu powołanej wyżej uchwały z 25 stycznia 2018 r., I KZP 13/17. Ograniczenia objętościowe niniejszego artykułu uniemożliwiły wyczerpujące omówienie tej argumentacji. 
Oznacza to, że jako organ rozpoznający skargę na wyrok sądu odwoławczego SN nie może badać merytorycznej zasadności zarzutów podniesionych w apelacji ściśle związanych z kwestią odpowiedzialności karnej. Z tego wynika, że SN nie będzie mógł na przykład oceniać, czy apelujący trafnie zarzucił sądowi a quo wadliwą ocenę społecznej szkodliwości czynu, która skutkowała umorzeniem postępowania na podstawie art. $17 \S 1$ pkt 3 k.p.k. w zw. z art. $1 \S 2$ k.k., a tym samym czy sąd odwoławczy miał słuszność, uznając ten zarzut za zasadny. Konkludujacc, należy zatem stwierdzić, że w postępowaniu zainicjowanym skargą na wyrok sądu odwoławczego SN zobowiązany jest do badania, jakiego rodzaju zarzut został podniesiony w apelacji, czy sąd odwoławczy go podzielił i czy podzielając go, miał podstawy do wydania, na podstawie art. $454 \S 1$ i 3 k.p.k., orzeczenia kastoryjnego.

O ile jednak na gruncie art. $454 \S 1$ i 3 k.p.k. konstatacja ta nie nasuwa większych wątpliwości - gdyż stwierdzenie, że orzeczenie sądu pierwszej instancji, o którym mowa w powołanych przepisach było wadliwe, z reguły wiązać się będzie z odmienną oceną materiału dowodowego, odmiennymi ustaleniami faktycznymi, czy też odmienną ocena prawną zachowania oskarżonego, która również siłą rzeczy musi być odniesiona do ustalonego w sprawie stanu faktycznego - o tyle wątpliwości powstaja na gruncie przesłanki wydania orzeczenia kasatoryjnego z powodu przesłanki określanej mianem „konieczności przeprowadzenia przewodu sądowego w całości”. Bez wątpienia potrzeba taka może wynikać zarówno z przyczyn natury dowodowej, jak i pozadowodowej. Jeśli chodzi o przyczyny dowodowe, to należy w pełni zgodzić się z wyrażanym w doktrynie poglądem, że potrzeba powtórzenia przewodu sądowego w całości zachodzi wówczas, gdy sąd pierwszej instancji nieprawidłowo przeprowadził lub ocenił wszystkie dowody albo nie przeprowadził lub nie ocenił żadnego dowodu ${ }^{26}$. Oznacza to, że prawidłowe przeprowadzenie lub ocena choćby jednego dowodu (np. z dokumentu) powoduje, iż analizowana przesłanka wydania wyroku kasatoryjnego się nie aktualizuje $\mathrm{e}^{27}$.

Jeśli chodzi natomiast o przyczyny pozadowodowe, to należy je wiązać z takimi naruszeniami przepisów procesowych, które powoduja że przewód sądowy jako całość dotknięty jest wada, która nie może być konwalidowana na etapie postępowania przed sądem drugiej instancji. Chodzi tu na przykład o takie uchybienia, jak rozpoznanie sprawy przez sędziego podlegajacego wyłączeniu na podstawie art. $41 \S 1$ k.p.k. bądź przeprowadzenie rozprawy pod nieobecność oskarżonego mimo braku skutecznego powiadomienia go o terminie rozprawy głównej. Na tej podstawie będzie się również opierać - w drodze wnioskowania a fortiori - wydanie wyroku kasatoryjnego w razie stwierdzenia, że konieczne jest przeprowadzenie przewodu sądowego, który w poprzednim postępowaniu nie był w ogóle prowadzony z uwagi na wydanie wyroku na skutek uwzględnienia wniosku złożonego na podstawie art. 335 $\S 1$ i 2 k.p.k. czy też art. 338a k.p.k. ${ }^{28}$

\footnotetext{
26 Świecki (2019): komentarz do art. 437, teza 24.

27 Świecki (2019): komentarz do art. 437, teza 24.

${ }^{28}$ Lach (2017): 268.
} 
Katalog przesłanek uzasadniajacych wydanie wyroku kasatoryjnego z uwagi na konieczność przeprowadzenia przewodu sądowego w całości jest zatem zróżnicowany, przy czym część z nich wiąże się z obrazą przepisów postępowania, której stwierdzenie nie wymaga dokonywania oceny materialnoprawnej trafności rozstrzygnięć zawartych w wyroku sądu pierwszej instancji. Powstaje w tym miejscu pytanie, czy i w tych sytuacjach SN nie jest uprawniony do badania, czy podniesiony w apelacji, a zaakceptowany przez sąd odwoławczy, zarzut jest trafny. W tych przypadkach, podobnie jak przy ocenie trafności decyzji organu ad quem co do wystapienia w danej sprawie bezwzględnej przyczyny odwoławczej, SN nie obejmowałby przecież swoją kontrolą trafności rozstrzygnięcia zawartego $\mathrm{w}$ wyroku sądu meriti $\mathrm{z}$ perspektywy jego materialnoprawnej słuszności, ale badałby, czy orzeczenie to dotknięte jest wada uzasadniajacca wydanie wyroku kasatoryjnego. Odwołując się do przykładu, można stwierdzić, że o ile nie budzi wątpliwości brak kompetencji SN do dokonywania w toku postępowania skargowego oceny trafności zarzutu apelacyjnego bazującego na tezie, że w sprawie nie została spełniona przesłanka wydania wyroku w trybie art. $335 \S 2$ k.p.k. w postaci braku wątpliwości co do okoliczności popełnienia przestępstwa i winy oskarżonego, o tyle w pełni dopuszczalne wydaje się prowadzenie analiz pod kątem tego, czy sąd odwoławczy miał rację, podzielając zarzut, że organ a quo wydał wyrok na skutek uwzględnienia wniosku, o którym mowa we wspomnianym przepisie, mimo że pokrzywdzony się temu sprzeciwił. Podobnie nie wydaje się budzić zastrzeżeń możliwość badania przez SN, czy prawidłowa była ocena sądu odwoławczego, że w sprawie należy ponownie przeprowadzić lub ocenić wszystkie dowody dokonywana nie tyle pod kątem ,jakościowym, ile ilościowym”, w celu ustalenia, czy rzeczywiście, na gruncie konkretnej sprawy, kwestionowany jest sposób przeprowadzenia lub oceny wszystkich dowodów czy tylko niektórych z nich. Za dopuszczalne należy również uznać badanie przez SN trafności oceny zarzutu bazującego na tezie, że rozprawę główną przeprowadzono pod nieobecność oskarżonego mimo tego, że nie został on skutecznie zawiadomiony o rozprawie głównej. Analiza prowadzona pod tym kątem niczym się w istocie nie różni od badania zasadności konstatacji sądu ad quem, że wyrok sądu pierwszej instancji dotknięty jest bezwzględną przyczyną odwoławczą z art. $439 \S 1$ pkt 11 k.p.k.

Dopuszczenie możliwości badania wspomnianych naruszeń prawa procesowego nie kłóci się ani z charakterem skargi jako nadzwyczajnego środka zaskarżenia, ani też z rolą SN jako organu powołanego do sprawowania nadzoru nad sądami powszechnymi i wojskowymi w zakresie orzekania. I przy tak zakreślonym zakresie kognicji nie mogłoby być mowy o dublowaniu kontroli odwoławczej.

W tym stanie rzeczy należy podzielić wyrażany w doktrynie pogląd, że choć zakres kontroli skargowej służy jedynie badaniu, czy sąd odwoławczy zasadnie uchylił zaskarżony wyrok i przekazał sprawę do ponownego rozpoznania, kontrola ta nie może ograniczyć się tylko do sprawdzenia, czy sąd odwoławczy podał formalnie dopuszczalna podstawę wydania wyroku kasatoryjnego. W jej toku winno się bowiem zbadać, czy w realiach konkretnej sprawy rzeczywiście 
zachodziła podstawa do wydania orzeczenia kasatoryjnego. Poza zakresem kontroli w postępowaniu skargowym musi natomiast pozostać prawidłowość stanowiska prawnego sądu odwoławczego co do istoty sprawy ${ }^{29}$.

Niezwykle istotnym zagadnieniem, zwiazanym z zakresem rozpoznania sprawy w toku postępowania skargowego, jest również kwestia, czy w toku tego postępowania SN może badać, czy wydanie wyroku kasatoryjnego na podstawie art. $437 \S 2$ k.p.k. nie było konsekwencja naruszenia przez sąd $a d$ quem przepisów wyznaczających granice rozpoznania sprawy w postępowaniu odwoławczym, oraz granice możliwych następstw tego rozpoznania, a mianowicie przepisów: art. $433 \S 1$ k.p.k. i art. $434 \S 1$ k.p.k., a także art. 435 k.p.k. i art. 440 k.p.k. Problem ten został dostrzeżony przez Prezesa Izby Karnej Sądu Najwyższego, który 7 stycznia 2019 r. zwrócił się o rozstrzygnięcie przez SN w składzie 7 sędziów następującego zagadnienia prawnego: „czy podstawy skargi na wyrok sądu odwoławczego, określone w art. 539a § 3 k.p.k., umożliwiają badanie w postępowaniu skargowym tego, czy sąd odwoławczy wydając wyrok orzekał w granicach zaskarżenia, a w razie podniesienia zarzutów w środku odwoławczym - także w granicach tych zarzutów (art. $433 \S 1$, art. $434 \S 1$ k.p.k.), a jeżeli orzekał niezależnie od granic zaskarżenia i podniesionych zarzutów (art. 435, art. 440 k.p.k.) - to czy wyrokując, nie naruszył przesłanek umożliwiających orzekanie w szerszym zakresie?"30.

Wydaje się, że na pytanie to należy udzielić generalnie odpowiedzi pozytywnej, mimo że art. 539a § 3 k.p.k. jako wyłączne podstawy wniesienia skargi wskazuje naruszenie art. 437 k.p.k. i uchybienia z art. $439 \S 1$ k.p.k.

Trzeba bowiem stwierdzić, że do naruszenia art. 437 k.p.k., a mówiąc ściślej: art. $437 \S 2$ k.p.k., może dojść nie tylko wtedy, gdy sąd, nie wychodząc poza wyznaczone przepisami k.p.k. granice rozpoznania sprawy i nie naruszając zakazu reformationis in peius, błędnie zastosuje ów przepis i dojdzie do przekonania, że zaistniały wymienione nim przesłanki do wydania wyroku uchylającego zaskarżony wyrok i przekazującego sprawę do ponownego rozpoznania, jak i wtedy, gdy zastosuje ów przepis, mimo że uniemożliwiał mu to dopuszczalny w danej sprawie zakres rozpoznania środka odwoławczego lub zakres możliwych rozstrzygnięć będących następstwem jego rozpoznania. $\mathrm{W}$ tym ostatnim przypadku naruszenie art. $437 \S 2$ k.p.k. nie będzie miało co prawda charakteru samodzielnego, a stanie się konsekwencją niedopuszczalnego wyjścia poza granice rozpoznania sprawy lub wydania orzeczenia wykraczającego poza możliwe następstwa rozpoznania środka odwoławczego, ale niewatpliwie zaistnieje ${ }^{31}$. Oczywiście w ostatnim opisanym układzie sytuacyjnym naruszenie wspomnianej regulacji może przybrać i podwójną postać, polegającą zarówno na zastosowaniu tego przepisu na skutek przekroczenia ww. granic, jak i obrazę samego art. $437 \S 2$ k.p.k., ale ta okoliczność nie podważa jednak trafności postawionej wyżej tezy.

${ }^{29}$ Sakowicz (2018): 172.

30 Zob. <http://www.sn.pl/sprawy/SitePages/Zagadnienia_prawne.aspx?ItemSID=1208-16544171 -be1b-4089-b74b-413997467af2\&ListName=Zagadnienia_prawne> [dostęp: 24.01.2019].

31 Por. wyrok SN z 13 lipca 2011 r., II KK 40/11, Lex nr 898596. 
Argumentu za dopuszczalnością opierania skargi na wyrok sądu odwoławczego na zarzucie zastosowania art. 437 § 2 k.p.k. na skutek naruszenia art. 433 i art. 434 k.p.k., art. 435 i art. 440 k.p.k. dostarcza również wnioskowanie a fortiori (a maiori ad minus). Skoro bowiem ustawodawca przyznał stronie kompetencję do złożenia skargi na wyrok sądu odwoławczego opartej na zarzucie naruszenia art. $437 \S 2$ k.p.k. przez wydanie wyroku kasatoryjnego mimo braku merytorycznych ku temu podstaw, to tym bardziej skarżacy winien mieć uprawnienie do tego, by móc zakwestionować zastosowanie owej regulacji w sytuacjach, gdy $\mathrm{z}$ uwagi na granice zaskarżenia, zarzuty odwoławcze i kierunek środka zaskarżenia oraz brak przesłanek do orzekania poza granicami zaskarżenia, już na przedpolu było to niemożliwe. Odwołaniu się do wspomnianego wnioskowania, które jest przecież wnioskowaniem z ,większego na mniejsze”, nie sprzeciwia się również wyjątkowy, podkreślony słowem „wyłaccznie”, charakter przedmiotowej regulacji ${ }^{32}$.

$\mathrm{O}$ ile jednak badanie, czy zastosowanie art. $437 \S 2$ k.p.k. nie było konsekwencją naruszenia przepisów art. $433 \S 1$ k.p.k. i art. 434 k.p.k., a nawet art. 435 k.p.k., nie sprzeciwia się istocie skargi na wyrok sądu odwoławczego, która uniemożliwia SN ocenę wyroku sądu pierwszej instancji przez pryzmat tego, czy jego treść spełnia standard sprawiedliwości prawnomaterialnej, o tyle badanie, czy sąd odwoławczy trafnie uznał, że granice rozpoznania sprawy wyznacza mu w tym przypadku także art. 440 k.p.k., może wywoływać wątpliwości. Pamiętać bowiem należy, że uznanie, iż orzeczenie jest rażąco niesprawiedliwe, może być spowodowane każdym z uchybień wymienionych w art. 438 k.p.k., a to oczywiście oznacza, że podstawą tej oceny mogą być na przykład rażące błędy w ustaleniach faktycznych czy rażący błąd popełniony na etapie subsumpcji ustalonego stanu faktycznego pod określoną normę prawną. Są to niewątpliwie uchybienia, które dotyczą „istoty sprawy”. Powyższe oznacza, że przyznanie SN kompetencji do badania, czy sąd odwoławczy trafnie uznał, że zaistniała przesłanka z art. 440 k.p.k., na podstawie wskazanych wyżej podstaw odwoławczych, oznaczałoby nic innego, jak opowiedzenie się za dopuszczalnością badania trafności stanowiska sądu odwoławczego co do istoty sprawy, co - jak wynika z poczynionych wyżej uwag w postępowaniu skargowym - jest wykluczone. Charakter przedmiotowego postępowania nie uniemożliwiałby jednak SN dokonania oceny, czy sąd odwoławczy zasadnie uznał, że zachodzi konieczność odwołania się do treści art. 440 k.p.k. z uwagi na zaistniałe w postępowaniu przed sądem pierwszej instancji poważne uchybienia natury czysto procesowej, rażąco godzące w standard sprawiedliwości proceduralnej.

Powyższe rozważania potwierdzają zatem postawioną wyżej tezę o generalnej dopuszczalności podnoszenia w skardze na wyrok sądu odwoławczego zarzutów dotyczących naruszenia przepisów art. 437 § 2 k.p.k. na skutek nieuprawnionego wyjścia przez sąd odwoławczy poza granice zaskarżenia lub

$32 \mathrm{~W}$ doktrynie od lat za dopuszczalne uznaje się odwołanie do wnioskowania a maiori ad minus przy interpretacji przepisów wyjątkowych, podlegających z tego względu ścisłej interpretacji - zob. Zoll (1926): 64. 
podniesione zarzuty oraz przełamanie kierunku zaskarżenia, z ograniczeniami wynikającymi z faktu, że w toku postępowania skargowego SN nie może badać trafności stanowiska instancji ad quem co do materialnoprawnej słuszności orzeczenia sądu pierwszej instancji.

IV. Z poczynionych wyżej uwag wynika, że choć zakres rozpoznania sprawy przez SN w toku postępowania zainicjowanego skargą na wyrok sądu odwoławczego jest nieco szerszy, niż mogłoby się wydawać z odczytywanego literalnie art. 539a $\S 3$ k.p.k., to jednak jest on zdecydowanie węższy niż zakres kontroli dokonywanej przez sąd na skutek wniesienia środka odwoławczego, a to przemawia za uznaniem za trafną decyzję prawodawcy, który ze skargi tej uczynił nadzwyczajny środek zaskarżenia.

Ta konstatacja nie jest jednak równoznaczna z uznaniem, że ustawodawca miał rację, wprowadzając omawiany instrument, w opisanym wyżej kształcie, na grunt polskiego procesu karnego. Pomijając powoływane we wstępnej części artykułu argumenty związane z brakiem jakichkolwiek empirycznie potwierdzonych podstaw do wnioskowania, że instytucja mająca na celu zagwarantowanie przestrzegania przez sądy odwoławcze przepisów zapobiegających nadmiernej kasatoryjności orzekania była rzeczywiście potrzebna - poważne wątpliwości wywołuje to, czy nadanie jej charakteru nadzwyczajnego środka zaskarżenia było adekwatne do stawianych przed tą instytucją celów. W tym kontekście przypomnieć wypada, że choć funkcji kontroli polegającej na korygowaniu błędów popełnionych przez ograny kontrolowane nie sposób przecenić, to jednak musi ona podlegać ograniczeniom, gdyż kontrola bezbrzeżna nie służy ani usprawnieniu postępowania, ani też polepszeniu jego wyników ${ }^{33}$.

$\mathrm{Na}$ wstępie należy zauważyć, że do tej pory nie traktowano nadzwyczajnych środków zaskarżenia jako instrumentów służących przyspieszeniu postępowania. Po części było to oczywiście związane z faktem, że dotychczas znane nadzwyczajne środki zaskarżenia przysługiwały od prawomocnych orzeczeń kończących postępowanie w sprawie, a tym samym - do czasu ich rozpoznania - mogły one - i to nie z mocy prawa - wpłynać jedynie na czas trwania postępowania wykonawczego. Przede wszystkim jednak środki zaskarżenia, których głównym celem jest eliminacja z obrotu prawnego nietrafnych rozstrzygnięć, zasadniczo przez ich uchylenie i przekazanie sprawy właściwemu sądowi do ponownego rozpoznania, siłą rzeczy nie mogą być uważane za instytucję służąca przyspieszeniu postępowania.

W przypadku skargi na wyrok sądu odwoławczego kwestia ta nabiera szczególnego znaczenia - i to nie tylko dlatego, że jedynym rozstrzygnięciem, jakie może zapaść w przypadku uznania jej za zasadna jest właśnie wyrok kasatoryjny - ale nade wszystko z tego powodu, że środek ten jest wnoszony od orzeczenia, które postępowania nie kończy, a to siła rzeczy powoduje, że samo jego wniesienie wpływa na czas trwania postępowania sądowego i - co wymaga zaakcentowania - nie zawsze ów wpływ można ocenić jako pozytywny.

${ }^{33}$ Gaberle (2000): 35. 
Z pewnością negatywnie na czas trwania postępowania sądowego skarga będzie oddziaływała w sytuacjach, gdy okaże się bezzasadna. W tych przypadkach czas, jaki zajmą czynności związane z jej wniesieniem i rozpoznaniem, bez wątpienia okaże się bezpowrotnie stracony. Nierzadko jednak wspomniany skutek skarga wywrze również w przypadkach, gdy okaże się zasadna. W sprawach mało obszernych, czy też niewymagajacych ponownego przeprowadzenia wszystkich dowodów, niejednokrotnie czas rozpoznania sprawy w postępowaniu ponownym może okazać się krótszy niż czas, jaki zajmie przeprowadzenie postępowania skargowego i ponowne badanie sprawy w postępowaniu odwoławczym.

Wnioski te potwierdza analiza danych dotyczacych okresu, jaki upływa między datą wydania orzeczenia przez sąd odwoławczy a datą wydania przez SN orzeczenia w przedmiocie skargi. Na podstawie opublikowanych orzeczeń SN, zapadłych po merytorycznym rozpoznaniu skargi na wyrok sądu odwoławczego w 2018 r. ${ }^{34}$, można obliczyć czas, jaki upłynął od dnia wydania wyroku przez sąd odwoławczy do dnia wydania orzeczenia przez $\mathrm{SN}^{35}$. Wyniki obliczeń przedstawiono w tabeli.

Tabela

\begin{tabular}{|c|c|c|c|c|c|c|c|c|}
\hline $\begin{array}{c}\text { Liczba } \\
\text { mie- } \\
\text { sięcy }\end{array}$ & $\begin{array}{c}\text { Powy- } \\
\text { żej } \\
2 \text { mies. }^{a)}\end{array}$ & $\begin{array}{c}\text { Powy- } \\
\text { żej } \\
\left.3 \text { mies. }{ }^{b}\right)\end{array}$ & $\begin{array}{c}\text { Powy- } \\
\text { żej } \\
4 \text { mies. }^{c)}\end{array}$ & $\begin{array}{c}\text { Powy- } \\
\text { żej } \\
\left.5 \text { mies. }^{d}\right)\end{array}$ & $\begin{array}{c}\text { Powy- } \\
\text { żej } \\
6 \text { mies. }^{e)}\end{array}$ & $\begin{array}{c}\text { Powy- } \\
\text { żej } \\
7 \text { mies. }\end{array}$ & $\begin{array}{c}\text { Powy- } \\
\text { żej } \\
8 \text { mies.g }^{g}\end{array}$ & $\begin{array}{c}\text { Powy- } \\
\text { żej } \\
9 \text { mies. }^{h)}\end{array}$ \\
\hline $\begin{array}{l}\text { Liczba } \\
\text { spraw }\end{array}$ & 9 & 21 & 24 & 18 & 7 & 5 & 1 & 1 \\
\hline
\end{tabular}

a) III KS 7/18; III KS 16/18; II KS 2/18; II KS 3/18; II KS 5/18; V KS 14/18; V KS 15/18; V KS 24/18; V KS 25/18; b) III KS 3/18; III KS 5/18; III KS 6/18; III KS 12/18; III KS 15/18; III KS 17/18; III KS 21/18; III KS 24/18; III KS 26/18; III KS 29/18; III KS 28/18; II KS 4/18; II KS 7/18; IV KS 27/18; IV KS 28/18; IV KS 29/18; V KS 6/18; V KS 8/18; V KS 16/18; V KS 20/18; V KS 26/18; c) III KS 11/17; III KS 2/18; III KS 4/18; III KS 12/17; III KS 9/18; III KS 8/18; III KS 11/18; III KS 13/18; III KS 22/18; III KS 23/18; II KS 8/18; IV KS 10/17; IV KS 3/18; IV KS 5/18; IV KS 6/18; IV KS 7/18; IV KS 12/18; IV KS 17/18; V KS 19/18; IV KS 24/18; V KS 3/18; V KS 4/18; V KS 18/18; V KS 21/18; d) III KS 18/18; III KS 19/18; III KS 27/18; IV KS 4/18; IV KS 13/18; IV KS 16/18; IV KS 18/18; IV KS 23/18; IV KS 25/18; IV KS 26/18; V KS 1/18; V KS 5/18; V KS 7/18; V KS 9/18; V KS 12/18; V KS 13/18; V KS 23/18; V KS 27/18; ${ }^{e)}$ IV KS 1/18; IV KS 8/18; IV KS 10/18; IV KS 14/18; IV KS 22/18; V KS 17/18; V KS 22/18; f) III KS 20/18; II KS 6/18; IV KS 9/18; IV KS 11/18; V KS 13/17; g) IV KS 15/18; h) IV KS 20/18 Źródło: opracowanie własne.

Natomiast średni czas trwania postępowania karnego w sądach rejonowych $\mathrm{w}$ pierwszej instancji w sprawach karnych zarejestrowanych $\mathrm{w}$ repertorium K w pierwszym półroczu 2017 r. wynosił 5,09 miesiąca, przy czym na 150674 sprawy 86636 zostało zakończonych w terminie do 3 miesięcy, a 35201 - w terminie powyżej 3 miesięcy do 6 miesięcy. Średni czas trwania postępowania w sprawach karnych w zarejestrowanych repertorium $\mathrm{K}$ w sadach okręgowych wynosił 7,7 miesiąca, przy czym na 2812 spraw 1192 zostały zakończone w terminie do 3 miesięcy, a 892 - w terminie powyżej 3 miesięcy

34 Według stanu na dzień 18 stycznia 2019 r.

35 Należy przy tym zauważyć, że zdecydowaną większość spraw KS Sąd Najwyższy rozstrzyga w terminie krótszym niż 2 miesiące. 
do 6 miesięcy. Z kolei średni czas rozpoznania apelacji w sądach apelacyjnych (sprawy AKa) zakończonych merytorycznym orzeczeniem wynosił 85 dni, a w sądach okręgowych (sprawy Ka) - 77,9 dnia ${ }^{36}$.

Należy przy tym zauważyć, że wśród orzeczeń SN będących podstawą powyższej analizy znajduje się 41 wyroków i 45 postanowień oddalających skargę, a to pozwala stwierdzić, że liczba zaskarżonych orzeczeń, które SN uznał za trafne, była co prawda minimalnie, ale jednak większa niż wyroków, które zostały uznane za nieprawidłowe. Ponadto odnotować wypada, że w 2018 r. bez rozpoznania zostało pozostawionych $12 \mathrm{skarg}^{37}$, a w jednym przypadku SN zwrócił akta sprawy sądowi odwoławczemu w celu podjęcia czynności zmierzających do usunięcia braków formalnych skargi ${ }^{38}$.

W świetle tych danych wykluczone wydaje się więc postawienie stanowczej i generalnej tezy, że skarga jest instrumentem, który wywiera pozytywny wpływ na czas trwania postępowania karnego, w którym została wniesiona.

Niewątpliwie - jako nadzwyczajny środek zaskarżenia, którego rozpoznanie zostało zastrzeżone do właściwości SN - skarga może jednak realizować inne funkcje, jakie przypisuje się środkom zaskarżenia, tj. funkcję stymulacyjną i precedensowa ${ }^{39}$. Szczególnie istotne znaczenie dla oceny zasadności przekonania ustawodawcy, iż skarga stanie się instrumentem, który usprawni przebieg postępowania karnego, będzie miał oczywiście stopień realizacji przez nią funkcji stymulacyjnej. Można bowiem podnieść argument, że choć postępowanie skargowe niejednokrotnie niepotrzebnie wydłuży czas rozpoznania konkretnej sprawy, to globalnie instytucja ta przyczyni się do usprawnienia procesu karnego, gdyż sama możliwość wniesienia skargi powstrzyma sądy odwoławcze przed bezpodstawnym wydawaniem kasatoryjnych orzeczeń w przyszłości. Rzecz jednak w tym, co sygnalizowano we wstępnej części artykułu, że tej kwestii empirycznie zbadać się nie da z uwagi na fakt, że przepisy wyznaczające nowy zreformowany model postępowania odwoławczego nie miały szansy „,sprawdzić się w praktyce”, zanim regulacje dotyczące skargi na wyrok sądu odwoławczego weszły w życie.

W świetle powyższych uwag uzasadnione jest natomiast pytanie, czy wyżej wymienionych funkcji nie mogłaby z powodzeniem spełnić inna, funkcjonująca w polskim porządku prawnym instytucja, której głównym celem jest właśnie zapobieganie przewlekłości postępowania, tj. skarga na naruszenie prawa strony do rozpoznania sprawy bez nieuzasadnionej zwłoki ${ }^{40}$. Powyż-

${ }^{36}$ Opracowanie Ministerstwa Sprawiedliwości, Podstawowa informacja o działalności sądów powszechnych - I półrocze 2017 roku na tle poprzednich okresów statystycznych, Warszawa, lipiec 2017: 21, 23, 24, 61, 63.

${ }^{37}$ III KS 1/18; III KS 10/18; III KS 14/18; III KS 25/18; II KS 1/18; II KS 6/17; IV KS 2/18; IV KS 21/18; V KS 2/18; V KS 10/18; V KS 11/18; V KS 19/18.

${ }^{38}$ II KS 9/18.

${ }^{39}$ Funkcja stymulacyjna polega na skłanianiu organów kontrolowanych do dbałości o prawidłowość wydawanych rozstrzygnięć oraz postępowania prowadzącego do ich wydania. Funkcja precedensowa utożsamiana jest natomiast $\mathrm{z}$ tworzeniem wzorcowych sposobów rozstrzygania problemów prawnych dla organów niższego rzędu - Gaberle (2000): 33.

${ }^{40}$ Instrument uregulowany w ustawie z 17 czerwca 2004 r. o skardze na naruszenie prawa strony do rozpoznania sprawy w postępowaniu przygotowawczym prowadzonym lub nadzorowa- 
sze wymagałoby oczywiście wyraźnego przesądzenia, że w toku postępowania zainicjowanego przedmiotową skargą możliwe jest badanie merytorycznej zasadności wydania przez sąd odwoławczy wyroku uchylającego zaskarżony wyrok i przekazującego sprawę do ponownego rozpoznania ${ }^{41}$, a także wprowadzenia, od dawna zresztą postulowanych, rozwiązań gwarantujących przeprowadzenie postępowania zainicjowanego wyżej wymienionym środkiem bez zakłócenia toku postępowania co do istoty sprawy ${ }^{42}$. Rzecz jednak wydaje się warta zachodu. Stymulowanie sprawności procesu instrumentem niezakłócającym przebiegu konkretnego postępowania wydaje się bowiem rozwiązaniem lepszym niż czynienie tego za pomoca nadzwyczajnego środka zaskarżenia, który - gdy okaże się bezzasadny - owo postępowanie tylko zbytecznie wydłuży, a gdy okaże się zasadny, jego realny wpływ na przyspieszenie rozpoznania sprawy da się zauważyć jedynie w niektórych przypadkach.

\author{
Maja Klubińska \\ Uniwersytet Mikołaja Kopernika w Toruniu \\ mklubinska@umk.pl \\ https://orcid.org/0000-0002-3909-2171
}

Czarnecki, P. (2016). Skarga na wyrok sądu odwoławczego. (Non)sens nowego rozdziału 55a Kodeksu postępowania karnego? Czasopismo Prawa Karnego i Nauk Penalnych 20(2): 77-105.

Gaberle, A. (2000). Funkcje kontroli instancyjnej w procesie karnym (zagadnienia podstawowe), [w:] A. Gaberle, S. Waltoś (red.), Środki zaskarżenia w procesie karnym. Księga pamiątkowa ku czci prof. Zbigniewa Dody. Kraków: 23-46.

Gil, D. (2016). Skarga na wyrok sądu odwoławczego jako nowy nadzwyczajny środek zaskarżenia w procesie karnym. Ius et Administratio 3: 81-95.

nym przez prokuratora i postępowaniu sądowym bez nieuzasadnionej zwłoki (t.jedn.: Dz. U. 2018, poz. 75), zwany najczęściej skargą na przewlekłość postępowania.

${ }^{41}$ Kwestia ta była bowiem judykaturze rozstrzygana niejednolicie. Sąd Najwyższy w postanowieniach z 27 października 2005 r., III SPP 142/05 (OSNP 2006, z. 9-10, poz. 167) oraz z 29 listopada 2004 r., III SPP 48/04 (OSNP 2005, z 5, poz. 75) dopuszczał możliwość badania w toku postępowania zainicjowanego skargą na przewlekłość postępowania merytorycznej zasadności wyroku sądu odwoławczego uchylającego zaskarżony wyrok i przekazującego sprawę do ponownego rozpoznania, a w konsekwencji stwierdzania przewlekłości postępowania z tego powodu, że wydanie przedmiotowego wyroku było bezzasadne. W uchwale składu 7 sędziów SN z 13 lutego 2008 r. III SPZP $2 / 07$ (OSNP 2009, z. 5-6, poz. 85) stwierdzono jednak, że zasadność wyroku sądu drugiej instancji uchylającego zaskarżony wyrok i przekazującego sprawę do ponownego rozpoznania z powodu nieważności (art. 386 § 2 k.p.c.) lub z powodu nierozpoznania przez sąd pierwszej instancji istoty sprawy, albo dlatego, że wydanie wyroku wymaga przeprowadzenia postępowania w całości (art. $386 \S 4$ k.p.c.) nie podlega ocenie na podstawie art. 12 ust. 2 ustawy z 17 czerwca 2004 r. o skardze na naruszenie prawa strony do rozpoznania sprawy w postępowaniu sądowym bez nieuzasadnionej zwłoki (Dz. U. Nr 179, poz. 1843). Aktualnie sądy zasadniczo zajmują stanowisko zbieżne z poglądem wyrażonym w ww. uchwale (por. np. postanowienia SN: z 9 lipca 2013 r., III SPP 128/13, Lex nr 1497166; z 22 kwietnia 2010 r., III SPP 8/10, Lex nr 602070).

${ }^{42}$ Powyższa uwaga związana jest $\mathrm{z}$ potrzebą wprowadzenia wyraźnego uregulowania zobowiązującego do sporządzania kopii akt sprawy (części akt sprawy) do dyspozycji czy to sądu orzekającego w sprawie, czy to sądu właściwego do rozpoznania skargi po to, by postępowanie zainicjowane wniesieniem skargi na przewlekłość postępowania nie wstrzymywało biegu postępowania co do istoty sprawy - zob. 11 tez o funkcjonowaniu skargi na przewlekłość, Helsińska Fundacja Praw Człowieka: 6; Kładoczny et al. (2017): 117. 
Hofmański, P. (1988). Samodzielność jurysdykcyjna sądu karnego. Katowice.

Hofmański, P., Waltoś, S. (2018). Proces karny. Zarys sytemu. Warszawa.

Kaftal, A. (1966). Prawomocność wyroków sądowych w polskim prawie karnym procesowym. Warszawa.

Kaftal, A. (1971). Kontrola prawomocnych orzeczeń w polskim procesie karnym. Warszawa.

Kładoczny, P. et al. (2011). Skarga na przewlekłość postępowania. Komentarz do ustawy o skardze na naruszenie prawa strony do rozpoznania sprawy w postępowaniu przygotowawczym prowadzonym lub nadzorowanym przez prokuratora i postępowaniu sądowym bez nieuzasadnionej zwłoki. Warszawa.

Koper, R. (2017). Środki przymusu w procesie karnym, [w:] K. Marszał, J. Zagrodnik (red.), Proces karny. Warszawa: 407-458.

Kulesza, C. (2012). Środki przymusu procesowego, [w:] P. Kruszyński (red.), Wykład prawa karnego procesowego. Białystok: 274-292.

Lach, A. (2017). Skarga na wyrok sądu odwoławczego, [w:] A. Lach (red.), Postępowanie karne po nowelizacji z 11 marca 2016 roku. Warszawa: 259-276.

Marszał, K. (2017). Postępowanie odwoławcze, [w:] K. Marszał, J. Zagrodnik (red.), Proces karny. Warszawa: 663-719.

Pawlikowska, J., Wantoła, M. (2016). Skarga na wyrok sądu karnego odwoławczego uchylający wyrok sądu pierwszej instancji, [w:] P. Czarnecki, M. Nowak (red.), Postępowanie odwoławcze w znowelizowanym Kodeksie postępowania karnego. Od sprzeciwu do kasacji - gradacja środków zaskarżenia. Kraków: 319-328.

Piasecki, K. (1962). Z problematyki uchylenia wyroku sądu pierwszej instancji i przekazania sprawy do ponownego rozpoznania. Palestra 9(57): 26-37.

Sakowicz, A. (2018). Zakres kontroli dokonywanej przez Sąd Najwyższy przy rozpoznaniu skargi na wyrok kasatoryjny sądu odwoławczego. Białostockie Studia Prawnicze 1: 155-173.

Steinborn, S. (2009). Gwarancyjna funkcja prawomocności i jej konsekwencje dla zakresu orzeczeń zdolnych do uprawomocnienia się [w:] J. Skorupka (red.), Rzetelny proces karny. Księga jubileuszowa Profesor Zofii Świdy. Oficyna, elektroniczna wersja publikacji - Lex.

Steinborn, S. (2011). Prawomocność części orzeczenia w procesie karnym. Lex.

Steinborn, S. (2017). Skarga na kasatoryjny wyrok sądu odwoławczego na tle systemu środków zaskarżenia w polskim procesie karnym, [w:] T. Grzegorczyk, R. Olszewski (red.), Verba volant, scripta manent. Proces karny, prawo karne skarbowe i prawo wykroczeń po zmianach z lat 2015-2016. Księga pamiątkowa poświęcona Profesor Monice Zbrojewskiej. WK - elektroniczna wersja publikacji - Lex.

Szymczykiewicz, R. (2016). Skarga na wyrok sądu odwoławczego jako nowy środek odwoławczy w polskiej procedurze karnej. Studia Prawnicze i Administracyjne 15(1): 99-108.

Świecki, D. (2019). Komentarz do art. 437, [w:] D. Świecki (red.), Kodeks postępowania karnego. Tom 2: Komentarz aktualizowany. Lex/el.

Tęcza-Paciorek, A., Wróblewski, K. (2017). Skarga na wyrok sądu odwoławczego. Palestra 9(62): $24-38$.

Wierczyński, G. (2003). Komentarz do § 1 załącznika, [w:] T. Bąkowski et al., Zasady techniki prawodawczej. Komentarz. ABC, elektroniczna wersja publikacji - Lex.

Zagrodnik, J. (2017). Instytucja skargi na wyrok sądu odwoławczego (rozdział 55a k.p.k.) - zarys problematyki, [w:] T. Grzegorczyk, R. Olszewski (red.), Verba volant, scripta manent. Proces karny, prawo karne skarbowe i prawo wykroczeń po zmianach z lat 2015-2016. Księga pamiątkowa poświęcona Profesor Monice Zbrojewskiej, WK: elektroniczna wersja publikacji - Lex.

Zoll, F. (1926). Polska ustawa o prawie autorskim i Konwencja berneńska. Warszawa. 


\section{COMPLAINTS AGAINST APPELLATE COURT JUDGEMENTS AS A MEANS OF APPEAL IN CRIMINAL PROCEEDINGS}

\section{Sum mary}

The regulations on complaints against appellate court judgements met with critical comments from the vast majority of legal sector representatives as early as during the legislative work. Yet, despite the fact this instrument has functioned in practice for over two years, it has not provided an opportunity to contest most of the arguments questioning the legitimacy of its implementation in the criminal proceedings in Poland, but it has also exposed a series of problems of interpretation which had been overlooked before. Apart from pointing out the mistakes made during the legislative work on the bill implementing the instrument in question, and the consequences thereof, the article discusses the issues associated with the character of a complaint as a legal remedy, and the scope of cognizance in appeal proceedings. Subsequently, conclusions regarding the legitimacy of the implementation of complaints in the criminal procedure in Poland and their influence on the duration of criminal proceedings are presented. Due to the fact that the major work on the article had been done by 1 February 2019, it does not discuss the legal problem presented to the Supreme Court on 7 February 2019 (I KZP 3/19).

Keywords: complaint against the appellate court judgment; extraordinary appeal measure; scope of control; complaint about the unreasonable time of proceedings 
